\title{
Application of Water Treated with Low-Temperature Low-Pressure Glow Plasma for Quality Improvement of Barley and Malt
}

\author{
Aneta Pater ${ }^{1, *(D)}$, Marek Zdaniewicz ${ }^{1}$, Paweł Satora ${ }^{1}$, Gohar Khachatryan ${ }^{2}$ and \\ Zdzisław Oszczęda ${ }^{3}$ \\ 1 Department of Fermentation Technology and Microbiology, Faculty of Food Technology, University of \\ Agriculture, Balicka Street 122, 30-149 Kraków, Poland; m.zdaniewicz@ur.krakow.pl (M.Z.); \\ pawel.satora@urk.edu.pl (P.S.) \\ 2 Department of Food Quality Analysis and Evaluation, Faculty of Food Technology, University of \\ Agriculture, Balicka Street 122, 30-149 Kraków, Poland; rrgchacz@cyf-kr.edu.pl \\ 3 Nantes Nanotechnological Systems, Dolne Młyny Street 21, 59-700 Bolesławiec, Poland; \\ oszczeda@nantes.com.pl \\ * Correspondence: a.pater@urk.edu.pl
}

Received: 7 January 2020; Accepted: 7 February 2020; Published: 10 February 2020

\begin{abstract}
The aim of this study is to determine the quality of water treated with low-temperature, low-pressure glow plasma, either in the air or under nitrogen, in order to obtain high-quality brewer's malt. To this end, plasma-treated spring water was used for barley grain soaking. In two-row spring barley grain, the procedure provided significantly higher water uptake capacity and grain sensitivity to water, as well as energy and germination capacity. The resulting malt showed improved moisture and 1000-grain mass. Furthermore, laboratory wort produced from the malt by the congress method did not differ statistically from a control sample in terms of filtration time, $\mathrm{pH}$, turbidity, color, extract, free amino nitrogen compounds, and aromatic composition.
\end{abstract}

Keywords: plasma-treated waters; barley; energy and germination capacity; water uptake capacity of the grain; malting

\section{Introduction}

Positive results in grain germination research [1] have led to the analysis of its applicability in brewing malt production processes, where germination plays a key role. Barley malt is the most important and necessary raw material in beer production. Generally, it is produced from two-row spring barley. Growing consumer demand for new beers has brought more attention to malts produced from other cereals, such as oat, wheat, buckwheat, and rye. However, barley malt has been historically accepted as the most common and appropriate cereal for the production of beer wort [2,3]. Due to the absence of active enzymes necessary for the hydrolysis of extractive components, barley seeds produce an amino-acid-poor extract of very high viscosity, which is also poor in adequate flavor and taste quality that is typical for beer [4]. Therefore, conducting the germination process in appropriate conditions is essential for the above-mentioned parameters, changing the biological, physical, and chemical properties of the seed and providing appropriate laxity [5]. The quality criteria for barley seed selected for brewing malt production are very precise. The brewing industry has imposed requirements and expects malthouses to deliver materials with high stability of basic seed components and performance characteristics [6]. The maximum protein concentration in barley used for the brewing malt production reaches $11.5 \%$. In some cases, this upper limit is difficult to maintain, due to varying protein content in 
the seed. Additionally, the crop-growing method, environment, and weather conditions often influence the protein content in brewing barley and are thus critical to consider [7].

Appropriately prepared malt, characterized by high-quality parameters, guarantees the proper progress of the technological process (i.e., short mashing time, the optimum composition of wort and beer, and highly efficient production) [8]. Germinated seed represents a natural source of amylolytic enzymes, such as alpha-amylases (solubilizing and dextrinizing enzymes) and beta-amylases (saccharifying enzymes) [9]. The above-mentioned enzymes are required in starch hydrolysis during the mashing process. They determine the selection of sugars (e.g., maltose) that may be used by the yeast during the fermentation process. The quality of barley for brewing is determined in lab malthouses. Extractivity—the level of extract obtained from the process, also known as extract efficiency-is a basic malt quality factor [10].

An instrument has recently been constructed to produce low-temperature, low-pressure glow plasma at low frequency (LPGP) [11], which was first used for water treatment. Białopiotrowicz et al. [12] reported the structure and selected physicochemical properties of water exposed to LPGP in the air. Studies have shown that water treated with LPGP changed its physical and selected physiochemical properties. That water contained aqueous clathrates with incorporated singlet oxygen molecules. For their size, these clathrates more readily permeated cell membranes, transporting excited oxygen molecules into the cells and tissues. These studies were then extended to the treatment of water with LPGP under nitrogen [13]. The stimulation of pathogenicity and reproduction of entomopathogenic fungi with such water was demonstrated. The positive effects of water treated with LPGP on soil micro-organisms and, hence, on the growth of various plants, providing enhanced crops and their quality, was described in a monograph by Tomasik [14]. Watering herbs with water treated with LPGP prepared in the air considerably changed the composition of the essential oils produced by peppermint [15]. Subsequently [16], treating water with LPGP under oxygen-free nitrogen was carried out. Depending on the time of the treatment, such water formed aqueous clathrates incorporating molecular nitrogen in its various excited states. Interesting effects of water treated with LPGP under nitrogen on the yield and composition of essential oils from basil have also been observed [17].

Such results of LPGP-treated water prompted us to check its applicability in producing high-quality brewer's malt. Particular attention is paid to the processes occurring in the malthouse and their impact on subsequent processes in the brewhouse (i.e., of a brewery).

It should be mentioned that various plasmas are available depending on the ways of their generation. Hence, there are different areas of their potential application. Recently reported plasmas [18-24] resemble LPGP neither in the methods of their generation nor in their character.

\section{Materials and Methods}

\subsection{Materials}

A concerto two-row barley variety with $11.75 \%$ moisture content and commercially available Żywiec Zdrój spring water were used.

\subsection{Methods}

\subsubsection{Water Treated with LPGP in the Air}

A total of $1500 \mathrm{~mL}$ of spring water (Żywiec Zdrój) in 2000-mL open Pyrex glass bottles was placed in a reactor chamber closely to a lamp generating plasma and exposed to plasma for $30 \mathrm{~min}$. Plasma at $38^{\circ} \mathrm{C}$ was generated in the lamp at $5 \times 10^{-3} \mathrm{mbar}, 600 \mathrm{~V}, 50 \mathrm{~mA}$, and $10 \mathrm{kHz}$ frequency. The chamber with the water sample remained at normal pressure. The water produced was stored at ambient temperature in 2000-mL closed Teflon containers. 


\subsubsection{Water Treated with LPGP under Nitrogen}

A total of $1500 \mathrm{~mL}$ of spring water (Żywiec Zdrój) was placed in 2000-mL open Pyrex glass bottles and a stream of nitrogen was bubbled through it for $15 \mathrm{~min}$. The nitrogen was deoxygenated by passing it through an absorber filled with an alkaline solution of resorcinol. After placing the bottles in the reactor, its chamber and the free space over the liquid were additionally filled with deoxygenated nitrogen. The conditions of treatment with LPGP and the storage of the product are the same as described in Section 2.2.1. The plasmothrone used in this study is visualized in Figure 1.
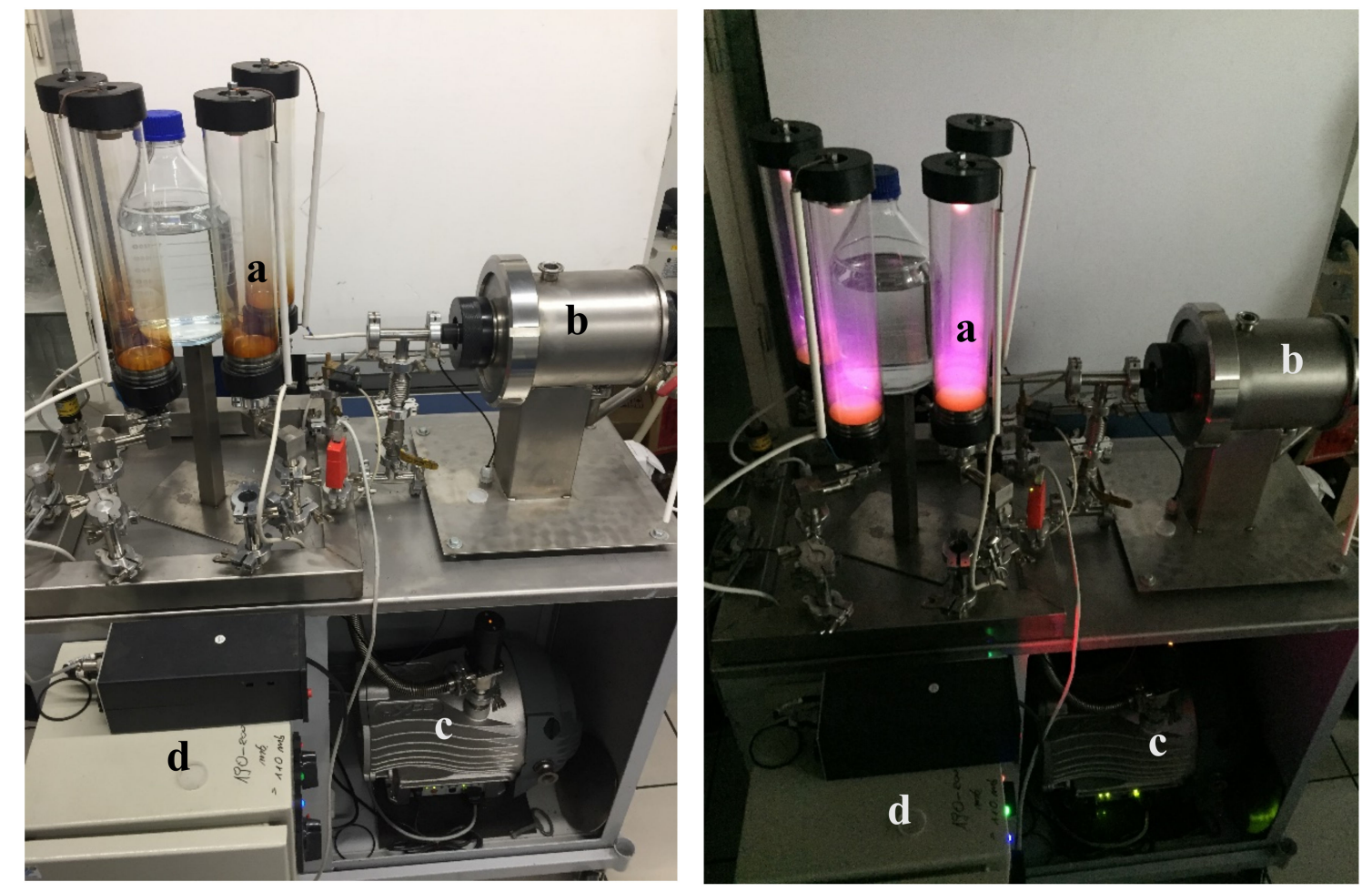

Figure 1. Plasmothrone (without cover) used in this study. (a) Lamps, (b) pulse generator, (c) vacuum pump, (d) power supply.

\subsubsection{Barley Malt}

Before the analysis, two-row spring barley variety seeds were sorted and purified. The malting process of the prepared barley involved water treated with LPGP, as described in Sections 2.2.1 and 2.2.2. A Pilsner-type malt was obtained as a result of the 6-day malting of $200 \mathrm{~g}$ brewing barley seed (Figure 2) in lab conditions at the Department of Fermentation Technology and Microbiology of the University of Agriculture in Kraków. The malting process proceeded in five stages, according to the instructions prepared by the Experimental Station for the Evaluation of Varieties (the Chem and Tech Lab) in Słupia Wielka, Poland [25]. 


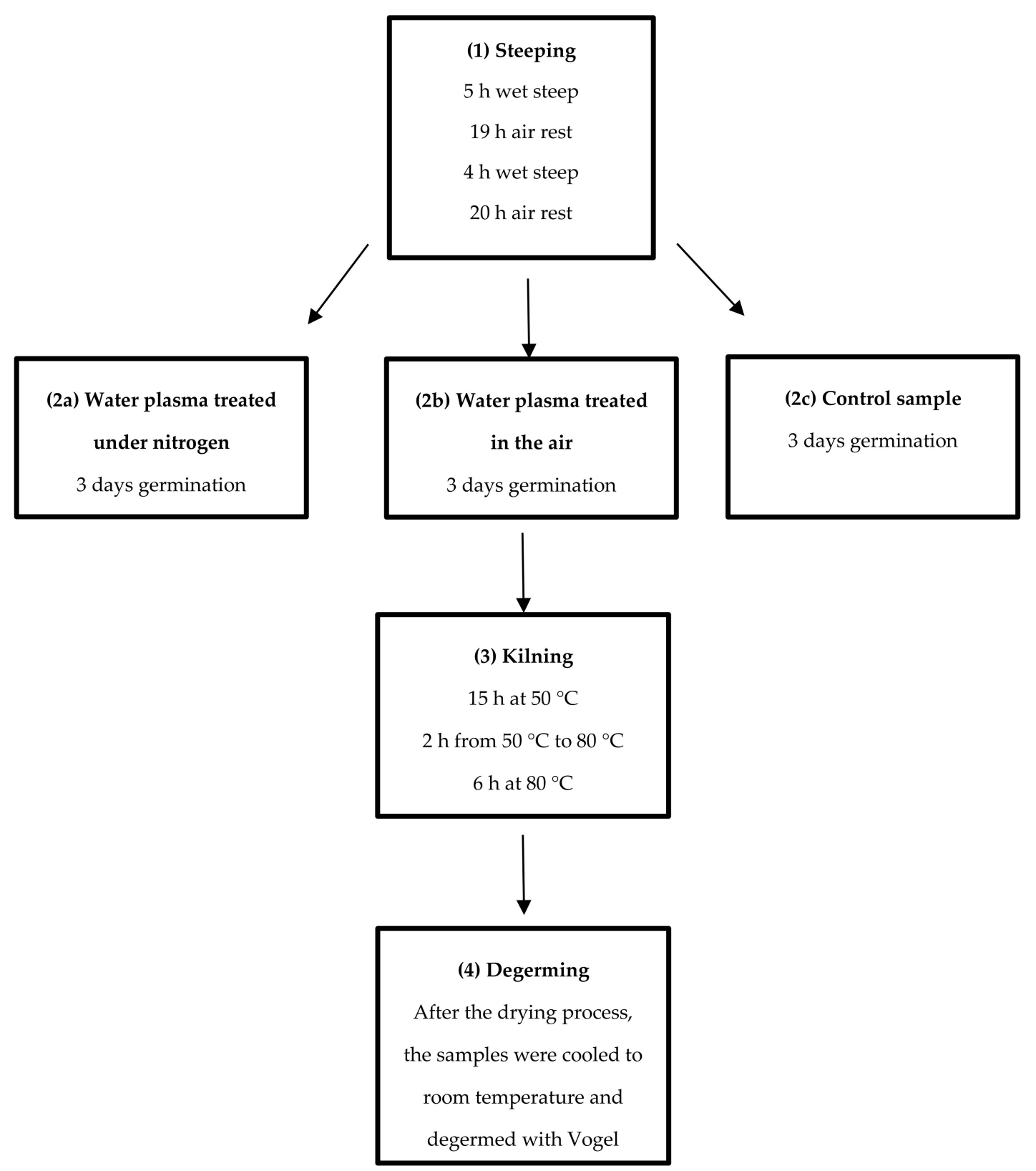

Figure 2. Malting process scheme.

\subsubsection{FTIR Spectral Characteristics of LPGP-Treated Waters}

The FTIR-ATR spectra of samples were recorded in the range of $4000-700 \mathrm{~cm}^{-1}$ at a resolution of $4 \mathrm{~cm}^{-1}$, using a Mattson 3000 FT-IR (Madison, WI, USA) spectrophotometer equipped with a 30SPEC $30^{\circ}$ reflectance adapter fitted with the MIRacle ATR accessory from PIKE Technologies Inc., Madison, Wisconsin, USA.

\subsubsection{Barley Analysis}

The water uptake capacity of the grain (W2) was tested by placing $200 \mathrm{~g}$ of sample barley $(11.75 \%$ moisture) in a pot and soaking in $200 \mathrm{~mL}$ plasma-treated water. After predefined soaking times $(5,12$, and $50 \mathrm{~h}$ ), the sample was weighed (after draining). Seed soaking was calculated from the obtained masses using the following formula:

$$
\mathrm{W} 2=100-\mathrm{M} 1 \cdot(100-\mathrm{W} 1) / \mathrm{M} 2
$$


where M1 and M2 are the sample masses $(\mathrm{kg})$ prior to and after soaking, respectively, and W1 and W2 are the original and after-soaking water contents $(\%)$, respectively.

Schönfeld's method was applied to determine the barley germination energy. Six portions of barley (500 seeds each) were placed in funnels and soaked in LPGP prepared either under nitrogen or in the air, or in non-treated water as a control. The funnels were covered with wet paper filters and Petri dishes. After $3 \mathrm{~h}$, the water was drained and the seeds were left for 18 to $20 \mathrm{~h}$. Then, the seeds were re-soaked in clamped funnels for $2 \mathrm{~h}$. After $72 \mathrm{~h}$, the non-germinated seeds were counted and soaked again in funnels for $30 \mathrm{~min}$. The germination procedure was conducted for $120 \mathrm{~h}$. Finally, the number of non-germinated seeds was determined [26].

Seed sensitivity to water was determined by placing an appropriate portion of barley (100 seeds) in Petri dishes, followed by soaking the grain in the analyzed waters ( 4 and $8 \mathrm{~mL}$ ). The number of germinated seeds was determined after $48 \mathrm{~h}$.

\subsubsection{Malt Analysis}

Acrospire length was determined by placing 20 malt seeds in conical flasks containing $40 \mathrm{~mL}$ $2 \% \mathrm{CuSO}_{4}$. The flasks were covered and boiled on a hot heating panel for $30 \mathrm{~min}$. Subsequently, the samples were cooled, placed in Petri dishes, and the length of their acrospires was estimated.

Seed moisture was analyzed by grinding malt in a malt graining lab mill for $12 \mathrm{~s}$. Then, $4 \mathrm{~g}$ of the malt from the sample was taken and placed in a MAC 50 moisture analyzer [27].

The mass of 1000 malt seeds was determined by weighing two approximately $40 \mathrm{~g}$ portions of barley. After removing damaged seeds and foreign bodies, the number of seeds was estimated [28].

Grading by grain size was analyzed by placing $100 \mathrm{~g}$ of seed sample on the frame of a sorting machine with appropriately located sieves $(2.2,2.5$, and $2.8 \mathrm{~mm})$. The sorting machine was run for $5 \mathrm{~min}$ and, afterwards, useful and useless impurities were removed from each sieve and transferred onto the bottom cover. The purified seed fraction and the residue on the bottom were weighted separately [29].

Extractivity was measured by preparing Congress mash using the EBC lab method. The extract was determined in the wort and the extractivity of the resultant malt was calculated [30].

Determination of protein content was carried out using the Dumas method. Approximately $0.5 \mathrm{~g}$ of the analyzed material was placed on tin foil. The foil was sealed and placed in a charging head. Subsequently, the system was sealed and degassed. The sample was burnt at $950{ }^{\circ} \mathrm{C}$ in pure oxygen. The combustion products were directed to a secondary afterburner $\left(850^{\circ} \mathrm{C}\right)$ for final oxidation and removal of impurities. Gases from the combustion process were stored inside a ballast tank, where they were homogenized and blended with pure helium. The gas mixture was then fed into a catalytic furnace filled with heated copper, where nitrogen oxides were reduced to $\mathrm{N}_{2}$. Lecosorb and Anhydrone reagents were used for purification from carbon dioxide and water. The gas mixture was then fed into a thermal conductivity detector to measure nitrogen content. The nitrogen content was converted into protein content $(\mathrm{g} / 100 \mathrm{~g})$ by multiplying the result by the appropriate coefficient ( 6.25 and 5.7, respectively).

All samples obtained from malting in tested waters were mashed in an R12 mash bath manufactured by 1-CUBE using the EBC method [30]. In the mashing process, mash saccharification time was analyzed. Subsequently, the content of the mash cup was cooled, filled with distilled water to reach $450 \mathrm{~g}$ of mass, and paper filtered. In order to ensure high clarity, the first portions of the filtrate were recirculated. Cleared wort (200 g) was boiled in round-bottom flasks heated to boiling point in heating mantles. During the boiling process, Octavia variety hops ( $7 \%$ of alpha acids) at an amount of $1.6 \mathrm{~g} / \mathrm{L}$ were added to the wort. Reflux condensers were used to reduce the vaporization of volatile hops compounds and boiling time was reduced to $30 \mathrm{~min}$. After boiling, the wort was cooled to $20^{\circ} \mathrm{C}$ and analyzed in six replicates. 


\subsubsection{Wort Analysis}

The $\mathrm{pH}$ of the lab wort was measured directly with a Mettler Toledo FiveGo $\mathrm{pH}$-meter. The $\mathrm{pH}$ meter was first calibrated with respective buffer solutions [31].

The lab wort color was measured by adding $0.5 \mathrm{~g}$ kieselguhr to reach $100 \mathrm{~mL}$ wort and paper filtering. The resultant wort was analyzed using a $25 \mathrm{~mm}$-thick cuvette in a Beckman DU-650 UV-vis spectrophotometer [32].

Wort extract density was measured directly with a DMA 35 density meter [33].

Wort turbidity was measured with a Nefelometr Cyberscan TN 100, which applied the nephelometric method in the range 0-1000 NTU, according to EN/ISO 7027, in order to measure turbidity.

Free mmino nitrogen (FAN) was determined by adding $2 \mathrm{~mL}$ diluted wort sample (1:50), $2 \mathrm{~mL}$ water (a blind sample), or $2 \mathrm{~mL}$ model glycine solution to three test tubes, as appropriate. Then, $1 \mathrm{~mL}$ ninhydrin was added to each test tube. Test samples were placed in a boiling water bath for $16 \mathrm{~min}$. After this time, samples were cooled for $20 \mathrm{~min}$ in a bath at $20{ }^{\circ} \mathrm{C}$. Subsequently, $5 \mathrm{~mL}$ diluting solution ( 2 g potassium iodate in $600 \mathrm{~mL}$ water and $400 \mathrm{~mL} \mathrm{96 \%} \mathrm{(v/v)} \mathrm{ethanol)} \mathrm{was} \mathrm{added} \mathrm{to} \mathrm{each} \mathrm{sample} \mathrm{and}$ mixed for $30 \mathrm{~min}$. The absorbance was measured at $570 \mathrm{~nm}$ (Beckman DU-650 UV-vis spectrometer) against water as a reference [34].

Volatile compound analysis involving solid-phase microextraction gas chromatography coupled with mass spectrometry (SPME-GC-MS)

In order to determine the volatiles, $1 \mathrm{~g} \mathrm{NaCl}$ and a 2-mL sample of wort were placed in a 10-mL vial, and an internal standard solution was added $(0.57 \mathrm{mg} / \mathrm{L}$ 4-methyl-2-pentanol, $0.2 \mathrm{mg} / \mathrm{L}$ anethol, and $1.48 \mathrm{mg} / \mathrm{L}$ of ethyl nonanoate; Sigma-Aldrich). An SPME device (Supelco Inc., Bellefonte, PA, USA) coated with PDMS $(100 \mu \mathrm{m})$ fiber was first conditioned by inserting it into a GC injector port for $1 \mathrm{~h}$ at $250{ }^{\circ} \mathrm{C}$. For sampling, the fiber was inserted into the headspace under stirring ( $300 \mathrm{rpm}$ ) for $30 \mathrm{~min}$ at $60^{\circ} \mathrm{C}$. Subsequently, the SPME device was introduced into the injector port of an Agilent Technologies $7890 \mathrm{D}$ chromatograph system equipped with LECO Pegasus HT, High Throughput TOFMS, and kept in the inlet for $3 \mathrm{~min}$. The SPME process was automated using the GERSTEL MultiPurpose Sampler (MPS).

The tested components were separated on an Rtx- 1 ms capillary column (Crossbond $100 \%$ dimethyl polysiloxane, $30 \mathrm{~m} \times 0.53 \mathrm{~mm} \times 0.5 \mu \mathrm{m}$ ). The detector was set at $250{ }^{\circ} \mathrm{C}$ and the column was heated using the following temperature program: $40^{\circ} \mathrm{C}$ for $3 \mathrm{~min}$, increment of $8{ }^{\circ} \mathrm{C} / \mathrm{min}$ to $230{ }^{\circ} \mathrm{C}$, then a constant temperature was maintained for $9 \mathrm{~min}$. Carrier: Helium at $1 \mathrm{~mL} / \mathrm{min}$ constant flow. EIMS electron energy: $70 \mathrm{eV}$; ion source temperature and connection parts: $250^{\circ} \mathrm{C}$. Analyte transfer was performed in splitless mode and the MSD was set to scanning mode (from $\mathrm{m} / \mathrm{z}=40$ to $\mathrm{m} / \mathrm{z}=400$ ). Compounds were identified using mass spectral libraries and linear retention indices, calculated from a series of n-alkanes (from C6 to C30).

The qualitative and quantitative identification of volatile substances (nonanal, decanal, 1-nonanol, 1-decanol, 1-dodecanol, ethyl hexanoate, ethyl octanoate, ethyl decanoate, ethyl dodecanoate, ethyl tetradecanoate, isocaryophyllene, humulene, and caryophyllene oxide; Sigma-Aldrich) were based on a comparison of retention times and peak surface area, as read from sample and standard chromatograms. Other detected components were determined semi-quantitatively $(\mu \mathrm{g} / \mathrm{L})$ by measuring the relative peak area of each identified compound, according to the National Institute of Standards and Technology NIST database (http://webbook.nist.gov/chemistry/), in relation to that of the internal standard. Each of the test was carried out in triplicate.

\subsection{Statistical Analysis}

The results presented in the paper are the means of six independent repetitions determining the standard deviation. The impact of the LPGP treated water (in the air and under nitrogen) on the analyzed parameters was determined using variance analysis and the significance of differences between the means was verified by using the post-hoc Tukey's test (Statistica 10, StatSoft Polska, Kraków). 


\section{Results and Discussion}

\subsection{Plasma Treated Water Analyses}

The FTIR spectra (Figure 3) of water in the range of $4000-1250 \mathrm{~cm}^{-1}$ consisted of two bands of $v_{\mathrm{OH}}$ combined into one broad peak and $\delta_{\mathrm{OH}}$ band at $1633 \mathrm{~cm}^{-1}$. The band situated at $3243 \mathrm{~cm}^{-1} \mathrm{was}_{\text {, }}$ in fact, composed of two bands reflecting asymmetric (longer wavelength; B-band) and symmetric (shorter wavelength; A-band) vibrations in the water molecule [35]. These could be recognized after the Gaussian distribution of that band. One can see that the positions of all three bands were insensitive to treatment with LPGP and that the intensity of those bands subtly depended on it (see Table 1).

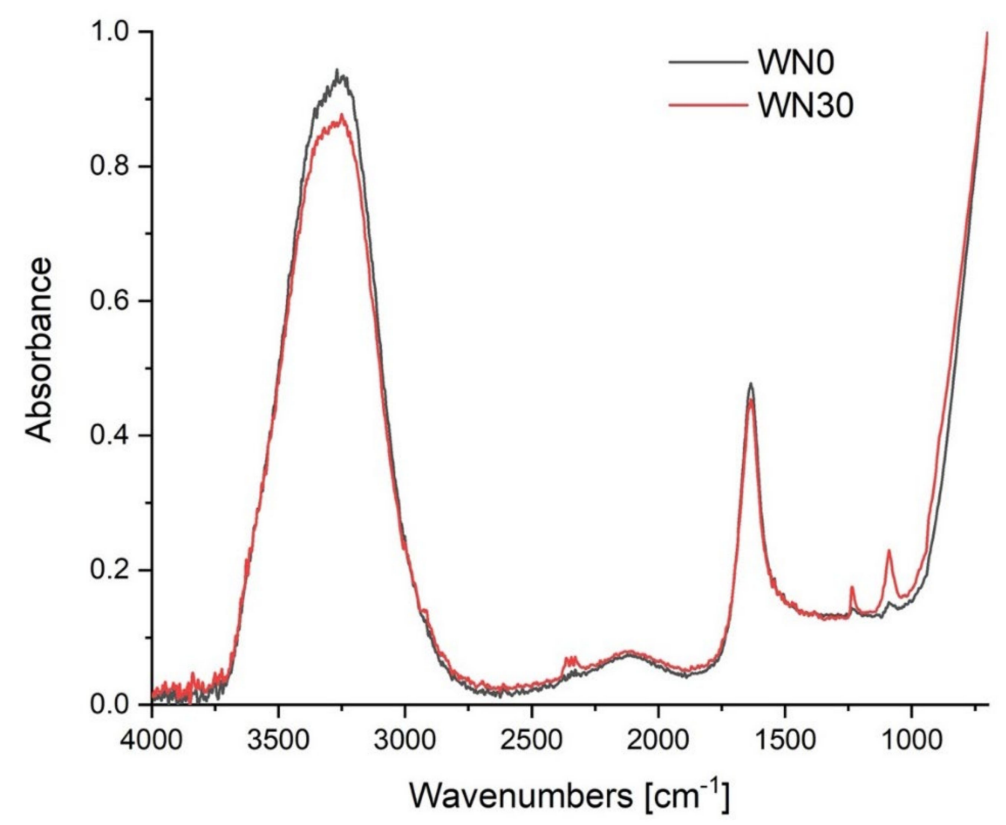

Figure 3. FTIR spectra of spring water from Żywiec Zdrój stored in contact with nitrogen prior to (WN0) and after treating with LPGP for $30 \mathrm{~min}$ (WN30).

Table 1. Intensity of $\mathrm{OH}$ stretching (bands $\mathrm{A}$ and $\mathrm{B}$ ) and bending (band C) modes in the FTIR spectra of water taken in the region of $4000-1500 \mathrm{~cm}^{-1}$.

\begin{tabular}{|c|c|c|c|c|c|c|}
\hline \multirow{2}{*}{ Sample } & \multicolumn{3}{|c|}{ Band Intensity } & \multicolumn{3}{|c|}{ Intensity Ratio } \\
\hline & A $\left(3494 \mathrm{~cm}^{-1}\right)$ & B $\left(3265 \mathrm{~cm}^{-1}\right)$ & $C\left(1633 \mathrm{~cm}^{-1}\right)$ & A/B & $\mathrm{A} / \mathrm{C}$ & $\mathrm{B} / \mathrm{C}$ \\
\hline WN 0 & 0.0810 & 0.3403 & 0.1732 & 0.238 & 0.468 & 1.965 \\
\hline WO 0 [12] & & & & 1.179 & & \\
\hline WN 30 & 0.0681 & 0.3294 & 0.1693 & 0.207 & 0.402 & 1.946 \\
\hline WO 30 [12] & & & & 1.3882 & & \\
\hline
\end{tabular}

Results for water plasma treated in the air have been published by Białopiotrowicz et al. [13]. They found that 30 min of LPGP treatment in the air favored the formation of asymmetrically vibrating water molecules with low, if any, dipole moment, making that water more hydrophobic; that is, more lipophylic (see an increase in the A/B intensity ratio). In the case of the LPGP-treated water under nitrogen, an opposite effect was observed. Plasma treatment for $30 \mathrm{~min}$ resulted in a decrease in the lipophylic properties of the water.

\subsection{Malt Analyses}

According to Kunze [2], the degree of water uptake characterizes a seed's capacity to absorb water (i.e., its swelling ability). The speed of water absorption by a seed depends on the duration of steeping, 
water temperature, seed size, protein content in barley, and aeration of the seed steeped underwater and without water [36]. In the initial stages of steeping, the water absorption rate of the seed reaches approximately $1 \%$ per hour. With increasing water saturation of the seed, a subsequent increase in moisture by $1 \%$ requires more than $5 \mathrm{~h}$ [37]. The higher the degree of soaking the grain, the better the material for barley malt. This also indicates that barley malt is characterized by higher enzyme activity and myelin of endosperm, which is very important in the later stages of beer production [38]. Grain steeping is also significantly affected by the temperature of the steeping water. During the malting process, water at 10 to $15^{\circ} \mathrm{C}$ is applied. Maintaining a constant water temperature during the entire seed steeping process is very important [39]. Before the steeping stage, the barley seed contained $11.75 \%$ moisture. Over the 5-h course of steeping, an intense increase in moisture was observed in seeds steeped in water plasma treated in the air and under nitrogen $(21.5 \%$ and $22 \%$, respectively), whereas the control sample after $5 \mathrm{~h}$ of steeping contained $18 \%$ moisture (see Table 2 ). When steeped in LPGP-treated water, after $12 \mathrm{~h}$ of steeping, close to $42 \%$ moisture was reached; following this, the moisture level remained unchanged until the end of steeping. In the control sample, the level of moisture at the 12 th hour was close to $38 \%$, which did not significantly increase in subsequent hours. These differences prove that the rate of the water absorption by the seed when using plasma-treated water was higher and that seed moisturizing was more efficient. This attribute is very important from the point of view of the cost-efficiency of malt production and identification of potential process shortcuts while avoiding an adverse impact on product quality.

Water absorption by grains, one of the basic parameters analyzed in a malthouse, is closely related to their sensitivity to water. When the water sensitivity of a grain is too high, appropriate steps must be taken to limit the steeping period. The seed sensitivity to water was determined based on the impact of two volumes of water ( 4 and $8 \mathrm{~mL}$ ) on the germination energy [40]. The water sensitivity of barley can be classified into low sensitivity (10\%), higher sensitivity (11-25\%), sensitive (26-45\%), and high sensitivity (over 45\%) [2]. This study proved (Table 2) that using water treated with plasma in the air and under nitrogen significantly increases the sensitivity of the grain and germination energy.

Barley germination capacity is one of the key properties determining the quality properties of a seed in terms of the percentage of seeds producing healthy and normally growing plants [41]. This parameter is defined according to the class of barley. In classes I and II, germination capacity should not be lower than $99 \%$, and $98 \%$ for class III [10]. Seed germination energy was determined after 3 and 5 days. High germination energy manifests the health of the seed and promises the normal progress of the malting process. In the analyzed samples, after the 3rd day of germination, a very significant difference in germination energy was observed in seeds steeped with water plasma-treated under nitrogen (95\%) and in the air (97.6\%). A similar effect was obtained after the 5th day of observation. A more positive impact was observed with water plasma treated in the air $(99.45 \%)$ than under nitrogen $(98.2 \%)$. Thus, based on the germination capacity, the barley could be categorized into classes I and II, respectively. The amount of non-germinated grain between days 3 and 5 of the process did not exceed 5\%, which, according to Kunze [2], manifests the health of the seed and promises the normal progress of the malting process (Table 2). Even a slight increase in seed germination capacity achieved in the process adds substantial indicators for the malthouse to its performance and the quality of malt it produces.

The moisture content parameter is used to test the storage stability of the malt. According to Angelno [42], moisture for pale malts should range from 3.8-7.3\%. In the non-treated samples, these values were slightly lower (3.6\%). The moisture of the malts from the process involving water plasma-treated under nitrogen and in the air fit the standard limits (5.4\% and 5.6\%, respectively). Taking into account the identical conditions of malt kilning and the analysis, differences between samples might have resulted from the fact that, before starting kilning, the seeds conditioned in plasma-treated water were slightly more steeped (42\%) than the control sample (39\%). These differences might also be associated with the reduced availability of structurally bound water in the case of samples treated with LPGP. 
Table 2. The quality parameters of barley and the obtained malts.

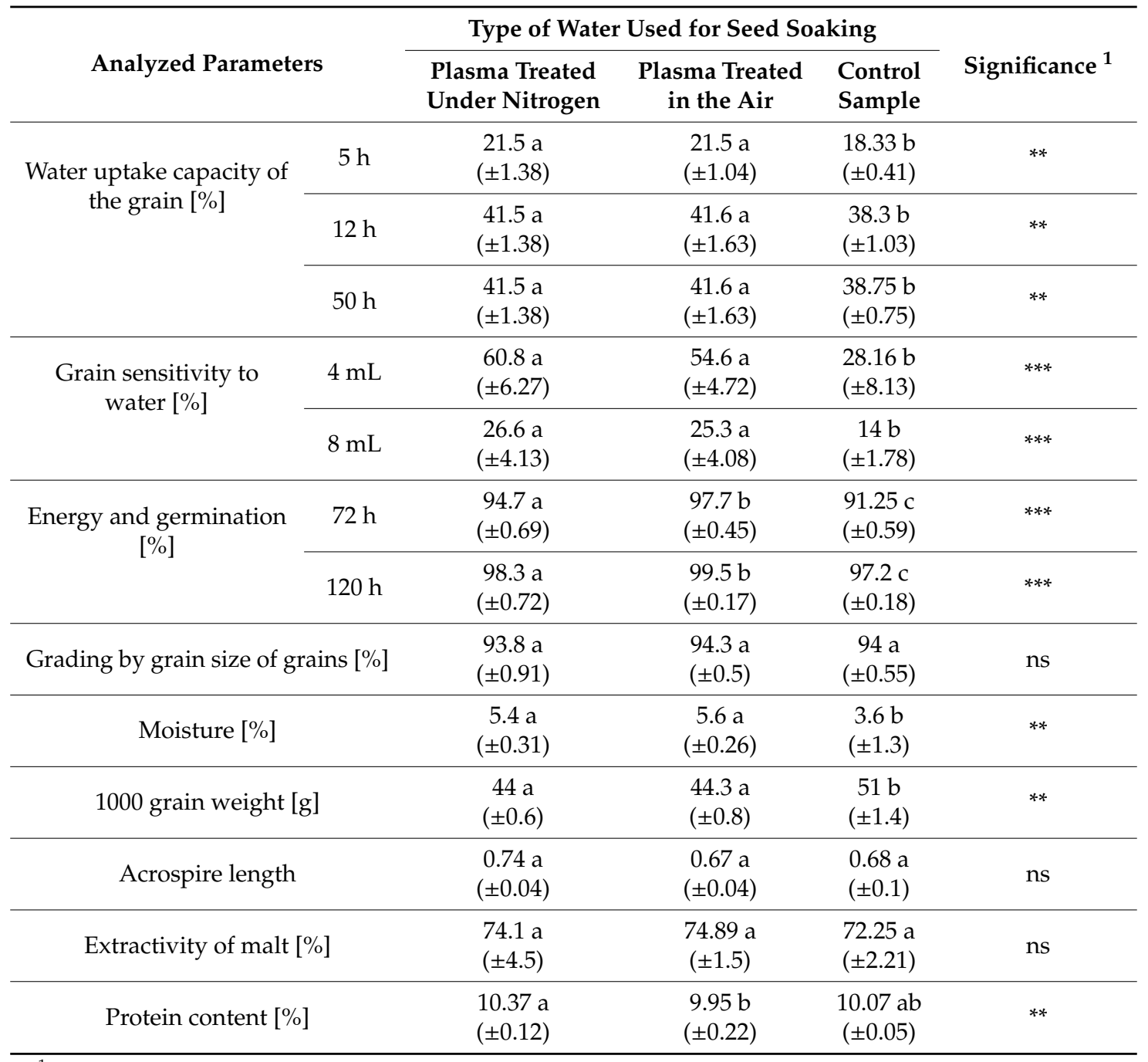

${ }^{1}$ Significance; ${ }^{* *}, * * *$ indicate significance at a level of $1 \%$ and $0.5 \%$, respectively, by the least significant difference; ns: not significant. Values with different superscript roman letters $(\mathrm{a}-\mathrm{c})$ in the same row are significantly different, according to the Duncan test $(p<0.05)$.

The grain uniformity of brewing barley should not be lower than $90 \%$ [43]. In the tests, independently of the water applied, grain uniformity in all variants reached approximately $94 \%$. High grain uniformity is important in the grinding process-the first stage in the malthouse-and for the adequate setting of space between rolls in a grinder. A mass of 1000 grains can be used to inform about the degree to which the seeds are filled with chemical components and their morphology, as well as finding the quantitative composition of the grinding products. In the literature, a very broad scope of results for the mass of 1000 seeds can be found. These studies had results ranging from 34.3 to $54.0 \mathrm{~g}$ [44-46]. By analyzing the mass of 1000 seeds and taking dry mass into account, significant differences were found between the control sample (51 g) and samples treated with LPGP (44 g).

One of the key parameters of malt quality is extraction yield (extractivity), which should not be lower than $79 \%$ for pale malts [2]. This parameter did not statistically significantly differ for the malts prepared within this experiment $74.1 \%$ and $74.9 \%$ for the treated samples and $72.2 \%$ for the control sample). The obtained malts had slightly lower extractivities than those described in the literature.

Protein content affects the quality of barley for beer brewing, which should range from $9.5-11.5 \%$. If barley seed has a higher protein content, the consequent extended steeping time leads to non-uniform germination throughout the entire malting process [47]. As a result, the quality of the malt deteriorates and the beer obtained is characterized by a lower quality [48]. Barley contains $10-12 \%$ protein [49], 
which can be estimated by sequential extraction efficiency, according to the procedure introduced by Osborne [50]. Hordein fractions extracted in the presence of a reducing factor represent $35-55 \%$ of all seed proteins and constitute the main barley storage protein [51]. In the malting process, barley proteins are partially decomposed into amino acids and small peptides by a number of proteolytic enzymes [52]. A good quality malt contains less than half of the hordeins occurring in the original barley [53]. The average protein content of the barley used in our experiments reached $10.5 \%$ before starting the malting process. This result was within the range required by the EBC. After the malting process, the protein content of grains steeped in water treated in the air reached $9.95 \%$, while grains steeped in water treated under nitrogen contained $10.37 \%$ protein. The results differed significantly. In the seed germination process, approximately $35-40 \%$ of proteins were transformed, and the outcome of the processes was expressed in terms of the Kolbach protein modification [54]. The level of protein in the malt was reduced against the initial content in the brewing barley seed (reaching 10.5\%), as a small part of it was used for developing radicals. After the malting process, the seeds steeped in water plasma treated in the air statistically significantly differed in protein content from the seeds steeped in water plasma-treated under nitrogen $(9.95 \%$ and $10.37 \%$, respectively). During the grain germination process, about $35-40 \%$ of the proteins change, and the effect of this process is visible in terms of the degree of protein relaxation, according to Kolbach [54]. The amount of protein in malt was reduced, as compared to the initial content in the malting barley grain, due to a small part of it being used for germination [55].

\subsection{Wort Analyses}

Ethanol, one of the main components of beer, is produced during the fermentation of the sugars developed by the hydrolysis of the starch present in wort. Starch yields mostly maltose and other products, such as dextrines, which cannot be fermented by yeast. Starch degradation proceeds in three stages: gelatinization, liquefaction, and saccharification. The time of malt saccharification in lab mashing, according to the Analytica EBC standard, cannot exceed 20 min [2,47]. Table 3 presents the results for the worts produced with the given malt variants. The wort produced in the process, after reaching $70^{\circ} \mathrm{C}$ in the mash bath, was characterized by saccharification after a period shorter than $5 \mathrm{~min}$. This proved the high enzymatic activity of the produced barley malt and appropriately selected malting parameters.

The results of color determination of the lab wort do not provide any specific information about the expected color of the final beer but, instead, solely indicate the type of malt used in its production. In the case of pale malts, the color of the wort should not be higher than $4 \mathrm{EBC}$ units and, for malts of average color, from 5-8 EBC units [2]. In this test, the color of the produced wort did not differ significantly (values between 3-4 EBC units). All the variants could be classified as pale malts. Similarly, no statistical differences were established for wort colors after boiling with hops (1.6 g/L OKTAWIA, alpha acid content $7 \%$; see Table 3). Prior to boiling, no statistically significant differences were reported for the samples. Turbidity is a parameter which has been analyzed in detail due to its relationship to wort quality [56]. This parameter, the type of material, the progress of the grinding process, and mashing are all very important. The turbidity of the wort is mainly influenced by the content of fats and fatty acids. The formation of a high content of proteins or protein-polyphenol complexes has been shown to contribute to increased turbidity [57].

The aromatic composition of the hopped wort depends on malt compounds, components formed during mashing, and substances derived from hops. Over $90 \%$ of the hop oil volatilizes during the boiling period and the traces are found in the hopped wort [58]. Alcohols, esters, and terpenes were the predominant aromatic compounds found in the tested wort (Table 4). No statistically significant differences were found in the content of volatile compounds in the analyzed samples; this means that the type of water used in grain soaking did not affect the aromatic composition. Moreover, no increase in the amount of oxidized compounds was noted, which would indicate the presence of a larger amount of free radicals and/or oxidizing agents in the raw materials used to obtain the wort. 
Table 3. Quality parameters of the obtained wort.

\begin{tabular}{|c|c|c|c|c|}
\hline \multirow[b]{2}{*}{ Analyzed Parameters } & \multicolumn{3}{|c|}{ Variety of Wort } & \multirow[b]{2}{*}{ Significance $^{1}$} \\
\hline & $\begin{array}{l}\text { Plasma Treated } \\
\text { under Nitrogen }\end{array}$ & $\begin{array}{l}\text { Plasma Treated } \\
\text { in the Air }\end{array}$ & Control Sample & \\
\hline Saccharification time (min) & $>5$ & $>5$ & $>5$ & ns \\
\hline Filtration time (min) & $\begin{array}{c}47 a \\
( \pm 25.63)\end{array}$ & $\begin{array}{c}74 \mathrm{a} \\
( \pm 33.36)\end{array}$ & $\begin{array}{c}46 \mathrm{a} \\
( \pm 32.62)\end{array}$ & ns \\
\hline Wort mass after filtration (g) & $\begin{array}{l}321.9 \mathrm{a} \\
( \pm 6.98)\end{array}$ & $\begin{array}{l}320.2 \mathrm{a} \\
( \pm 13.8)\end{array}$ & $\begin{array}{l}331.6 \mathrm{a} \\
( \pm 14.1)\end{array}$ & ns \\
\hline $\mathrm{pH}$ & $\begin{array}{l}6.02 \mathrm{a} \\
( \pm 0.04)\end{array}$ & $\begin{array}{l}6.02 \mathrm{a} \\
( \pm 0.02)\end{array}$ & $\begin{array}{c}6.03 \mathrm{a} \\
( \pm 0.03)\end{array}$ & ns \\
\hline Turbidity (EBC) & $\begin{array}{l}14.91 \mathrm{a} \\
( \pm 7.15)\end{array}$ & $\begin{array}{l}14.69 \mathrm{a} \\
( \pm 7.46)\end{array}$ & $\begin{array}{l}12.74 \mathrm{a} \\
( \pm 4.6)\end{array}$ & ns \\
\hline Color (EBC units) & $\begin{array}{c}3 \mathrm{a} \\
( \pm 0.85)\end{array}$ & $\begin{array}{c}4 \mathrm{a} \\
( \pm 0.58)\end{array}$ & $\begin{array}{c}3 \mathrm{a} \\
( \pm 0.62)\end{array}$ & ns \\
\hline Wort extract $\left({ }^{\circ} \mathrm{P}\right)$ & $\begin{array}{c}8 \mathrm{a} \\
( \pm 0.47) \\
\end{array}$ & $\begin{array}{l}8.12 \mathrm{a} \\
( \pm 0.33)\end{array}$ & $\begin{array}{l}8.12 \mathrm{a} \\
( \pm 0.17)\end{array}$ & ns \\
\hline $\mathrm{pH}$ after boiling & $\begin{array}{c}5.95 \mathrm{a} \\
( \pm 0.01) \\
\end{array}$ & $\begin{array}{c}5.99 \mathrm{a} \\
( \pm 0.02) \\
\end{array}$ & $\begin{array}{c}5.98 \mathrm{a} \\
( \pm 0.01) \\
\end{array}$ & ns \\
\hline Wort color after boiling (EBC) & $\begin{array}{c}5 \mathrm{a} \\
( \pm 0.03) \\
\end{array}$ & $\begin{array}{c}5 \mathrm{a} \\
( \pm 0.02)\end{array}$ & $\begin{array}{c}5 \mathrm{a} \\
( \pm 0.01)\end{array}$ & ns \\
\hline Wort extract after boiling $\left({ }^{\circ} \mathrm{P}\right)$ & $\begin{array}{c}8.5 \mathrm{a} \\
( \pm 0.01) \\
\end{array}$ & $\begin{array}{c}8.5 \mathrm{a} \\
( \pm 0.00) \\
\end{array}$ & $\begin{array}{c}8.5 \mathrm{a} \\
( \pm 0.00) \\
\end{array}$ & ns \\
\hline Turbidity after boiling (EBC) & $\begin{array}{l}139.01 \mathrm{a} \\
( \pm 0.29)\end{array}$ & $\begin{array}{l}137.72 \mathrm{a} \\
( \pm 0.08)\end{array}$ & $\begin{array}{l}177.4 \mathrm{~b} \\
( \pm 12.48)\end{array}$ & $* *$ \\
\hline $\begin{array}{l}\text { Free amino nitrogen in wort } \\
\text { (FAN; } \mathrm{mg} / \mathrm{L})\end{array}$ & $\begin{array}{l}132.6 \mathrm{a} \\
( \pm 19.4)\end{array}$ & $\begin{array}{l}123.6 \mathrm{a} \\
( \pm 19.1)\end{array}$ & $\begin{array}{l}132.2 \mathrm{a} \\
( \pm 8.87)\end{array}$ & ns \\
\hline
\end{tabular}

Table 4. Aromatic composition of the obtained hopped wort.

\begin{tabular}{|c|c|c|c|c|c|}
\hline Compound $(\mu \mathrm{g} / \mathrm{L})$ & LRI $^{2}$ & $\begin{array}{l}\text { Plasma Treated } \\
\text { Under Nitrogen }\end{array}$ & $\begin{array}{l}\text { Plasma Treated } \\
\text { in the Air }\end{array}$ & $\begin{array}{l}\text { Control } \\
\text { Sample }\end{array}$ & Significance $^{1}$ \\
\hline \multicolumn{6}{|l|}{ Esters } \\
\hline Ethyl octanoate & 1180 & $3.35 \mathrm{a}$ & $0.00 \mathrm{~b}$ & $2.68 \mathrm{a}$ & $* *$ \\
\hline Ethyl 2-methyloctanoate 3 & 1209 & 8.4 & 7.8 & 6.1 & ns \\
\hline Propyl nonanoate ${ }^{3}$ & 1373 & 0.09 & 0.08 & tr. & ns \\
\hline Ethyl decanoate & 1397 & 0.08 & tr. & tr. & ns \\
\hline Ethyl dodecanoate & 1581 & 0.07 & tr. & tr. & ns \\
\hline Ethyl tetradecanoate & 1790 & tr. & tr. & tr. & ns \\
\hline \multicolumn{6}{|l|}{ Alcohols } \\
\hline 1-Hexanol, 2-ethyl- ${ }^{3}$ & 1020 & 129.6 & 101.2 & 133.3 & ns \\
\hline 1-Octanol, 2-methyl- ${ }^{3}$ & 1119 & 27.6 & 21.6 & 25.6 & ns \\
\hline 1-Nonanol & 1156 & 143.2 & 95.5 & 134.1 & ns \\
\hline 1-Heptanol, 2-propyl-33 & 1203 & 0.08 & 0.12 & 0.18 & ns \\
\hline Ethanol, 2-[(2-ethylhexyl)oxy]-3 & 1226 & 1.38 & 3.18 & 2.40 & ns \\
\hline 1-Decanol & 1272 & 0.59 & 1.28 & 1.34 & ns \\
\hline 1-Undecanol ${ }^{3}$ & 1368 & 0.10 & 0.12 & 0.55 & ns \\
\hline 2-Dodecanol ${ }^{3}$ & 1417 & tr. & 0.06 & 0.06 & ns \\
\hline 1-Dodecanol & 1480 & tr. & tr. & 0.07 & ns \\
\hline
\end{tabular}


Table 4. Cont.

\begin{tabular}{|c|c|c|c|c|c|}
\hline Compound $(\mu \mathrm{g} / \mathrm{L})$ & $\mathrm{LRI}^{2}$ & $\begin{array}{l}\text { Plasma Treated } \\
\text { Under Nitrogen }\end{array}$ & $\begin{array}{l}\text { Plasma Treated } \\
\text { in the Air }\end{array}$ & $\begin{array}{l}\text { Control } \\
\text { Sample }\end{array}$ & Significance $^{1}$ \\
\hline \multicolumn{6}{|l|}{ Terpenes } \\
\hline Isocaryophyllene & 1414 & tr. & tr. & tr. & ns \\
\hline trans- $\alpha$-Bergamotene ${ }^{3}$ & 1432 & tr. & tr. & tr. & ns \\
\hline Humulene & 1455 & $0.59 \mathrm{a}$ & $0.47 \mathrm{a}$ & tr. $b$ & $*$ \\
\hline D-Germacrene ${ }^{3}$ & 1485 & tr. & tr. & tr. & ns \\
\hline$\alpha$-Farnesene ${ }^{3}$ & 1490 & 0.59 & 1.66 & 2.20 & $\mathrm{~ns}$ \\
\hline Caryophyllene oxide & 1578 & 0.05 & 0.07 & tr. & ns \\
\hline Humulene epoxide II $^{3}$ & 1606 & 0.18 & 0.15 & tr. & ns \\
\hline \multicolumn{6}{|l|}{ Carbonyl Compounds } \\
\hline Nonanal & 1102 & 8.37 & 3.82 & 5.31 & ns \\
\hline Decanal & 1182 & 24.8 & 28.2 & 25.4 & ns \\
\hline 9-Oxabicyclo [6.1.0]nonan-4-one ${ }^{3}$ & 1212 & 0.30 & 0.86 & 0.65 & ns \\
\hline \multicolumn{6}{|l|}{ Other Compounds } \\
\hline 2-Acetyl-2,3,5,6-tetrahydro-1,4-thiazine ${ }^{3}$ & 1345 & tr. & tr. & tr. & ns \\
\hline Octane, $1,1^{\prime}$-oxybis- ${ }^{3}$. & 1657 & tr. & tr. & tr. & ns \\
\hline
\end{tabular}

Other parameters analyzed in the test, such as filtration time, the mass of the wort from the process, $\mathrm{pH}$, and free amino nitrogen (FAN) content, did not show any statistically significant differences.

\section{Conclusions}

The results of the conducted experiments indicate that water treated with low-temperature, low-pressure plasma in the air and under nitrogen can improve the malting process in the brewing industry, providing a better quality of the brewing malt. Significantly higher water uptake capacity of the grain and grain sensitivity to water, as well as energy and germination capacity for two-row spring barley grain, were observed. Quality parameters pointed to statistically significant improved moisturizing and 1000-grain mass. Other malt parameters, such as extractivity and acrospire length, did not change in any manner. Laboratory wort produced from obtained malts by the congress method did not differ statistically in terms of filtration time, $\mathrm{pH}$, turbidity, color, extract, free nitrogen compounds, and aromatic composition. Thus, it has been proved that water treated with low-temperature, low-pressure glow plasma in the air and under nitrogen has no negative effect on the mashing process.

Author Contributions: Conceptualization, M.Z., P.S., and A.P.; methodology, A.P. and M.Z.; software, A.P. and P.S.; validation, A.P. and M.Z.; formal analysis, A.P. and P.S.; investigation, A.P.; resources, G.K. and Z.O.; data curation, A.P.; writing - original draft preparation, A.P.; writing-review and editing, P.S., M.Z. and G.K.; visualization, A.P.; supervision, M.Z.; project administration, A.P.; funding acquisition, M.Z. All authors have read and agreed to the published version of the manuscript.

Funding: This work was financially supported by Grant LIDER 46/0185/L-9/17/NCBR/2018.

Conflicts of Interest: The authors report no conflicts of interest. The authors alone are responsible for the content and writing of the paper.

\section{References}

1. Michalak-Majewska, M.; Makarska, E. Effect of the process of spring barley grain germination on the nutritive value of protein. Acta Agrophys. 2009, 14, 649-658. (In Polish) 
2. Kunze, W. Technology Brewing and Malting; Westkreuz-Druckerei Ahrens KG: Berlin/Bonn, Germany, 2014.

3. Łacny, K.; Janczar-Smuga, M. Technical and technological progress in malt production. Nauki Inż. Technol. 2013, 4, 77-93. (In Polish)

4. Lewis, M.J.; Young, T.W. Malt Technology: Malt, specialized malts and non-malt adjuncts. In Brewing; Springer: Boston, MA, USA, 2001; Volume 2, pp. 149-161. [CrossRef]

5. Leśniak, W. Food Biotechnology. Fermentation and Biosynthesis Processes; Office of University of Economy: Wrocław, Poland, 2002; pp. 21-26. (In Polish)

6. Molina-Cano, J.L. The EBC Barley and malt Committee Index for the Evaluation of Quality Malting in Barley and its USE in Breeding. Plant Breed. 1987, 98, 249-256. [CrossRef]

7. Bertholdsson, N.O. Characterization of malting barley cultivars with more or less stable grain protein content under varying environmental conditions. Eur. J. Agron. 1999, 10, 1-8. [CrossRef]

8. de Tempe, J. Routine methods for determining the health condition of seeds in seed tasting station. Proc. Int. Seed Test. Assoc. 1970, 35, 257-296.

9. Strak, E.; Balcerek, M. Malts as a source of amylolytic enzymes in the process of enzymatic hydrolysis of starch (in Polish). Żywn. Nauk. Technol. Jakość. 2016, 6, 41-54. [CrossRef]

10. Gasiorowski, H. Technological value of barley and some methods of its assessment. In Barley-Chemistry and Technology; Office PWEiL: Warsaw, Poland, 1997; pp. 263-271. (In Polish)

11. Oszczęda, Z.; Elkin, I.; Stręk, W. Equipment for Treatment of Water with Plasma. Polish Patent PL 216025 B1 (2014). Polish Patents Database. Available online: https:/grab.uprp.pl/PropertiesProtection/Site\%20pages/ Quick\%20search.aspx?wersja=english (accessed on 4 February 2020).

12. Białopiotrowicz, T.; Ciesielski, W.; Domanski, J.; Doskocz, M.; Khachatryan, K.; Fiedorowicz, M.; Graż, K.; Koloczek, H.; Kozak, A.; Oszczęda, Z.; et al. Structure and physicochemical properties of water treated with low-temperature low-frequency glow plasma. Curr. Phys. Chem. 2016, 6, 312-320. [CrossRef]

13. Chwastowski, J.; Ciesielska, K.; Ciesielski, W.; Khachatryan, K.; Kołoczek, H.; Kulawik, D.; Oszczęda, Z.; Tomasik, P.; Witczak, M. Structure and physiochemical properties of water treated under nitrogen with low-temperature glow plasma. Water Sci. Technol. 2019, in press.

14. Jaworska, M.; Oszczęda, Z.; Tomasik, P. Water treated with low-temperature, low-pressure, low-frequency glow plasma as a stimulant of pathogenicity and reproduction of bioesticides. Part, I., Entomopathogenic fungi. Pol. J. Nat. Sci. 2018, 33, 561-568.

15. Tomasik, P. Fundamentals of Nanotechnology of Food and Cosmetics; Sophia Science Editorial Office: Warsaw, Poland, 2019; pp. 61-68. (In Polish)

16. Pisulewska, E.; Ciesielski, W.; Jackowska, M.; Gąstoł, M.; Oszczęda, Z.; Tomasik, P. Effect of water treated with low-pressure, low-temperature glow plasma of low frequency on planted peppermint (Mentha piperita). EJPAU Ser. Biotechnol. 2018, 21. [CrossRef]

17. Ciesielski, W.; Gąstoł, M.; Girek, T.; Kulawik, D.; Oszczęda, Z.; Pisulewska, E.; Tomasik, P. Water treated with low-pressure, low-temperature glow plasma affects the growth and essential oil basil (Ocinum bacilicum L.). Innov. Food Sci. Emerg. Technol. 2019, in press.

18. Scholtz, V.; Khun, J.; Šerá, B. Nonthermal plasma for food quality and safety. J. Food Qual. 2019, $2019,6468018$. [CrossRef]

19. Scholtz, V.; Šerá, B.; Khun, J.; Šery, M.; Julak, J. Effects of nonthermal plasma on wheat grains and products. J. Food Qual. 2019, 2019, 7917825. [CrossRef]

20. Held, S.; Tyl, C.E.; Annor, G.A. Effect of radio frequency cold plasma treatment on intermediate wheatgrass (Thinopyrum intermedium) flour and dough properties in comparison to hard and soft wheat (Triticum aestivum L.). J. Food Qual. 2019, 2019, 10855172. [CrossRef]

21. Gebremical, G.G.; Emire, S.A.; Berhanu, T. Effects of multihollow surface dielectric barrier discharge plasma on chemical and antioxidant properties of peanut. J. Food Qual. 2019, 2019, 3702649. [CrossRef]

22. Zhuang, H.; Rothrock, M.J., Jr.; Hiett, K.L.; Lawrence, K.C.; Gamble, G.R.; Bowker, B.C.; Keener, K.M. In-package air cold plasma treatment of chicken breast meat: Treatment time effect. J. Food Qual. 2019, 2019, 1837351. [CrossRef]

23. Lee, J.H.; Woo, K.S.; Jo, C.; Jeong, H.S.; Lee, S.K.; Lee, B.W.; Lee, Y.Y.; Lee, B.; Kim, H.J. Quality evaluation of rice treated by high hydrostatic pressure and atmospheric pressure plasma. J. Food Qual. 2019, 2019, 4253701. [CrossRef] 
24. Chang, E.H.; Bae, Y.S.; Shin, I.S.; Choi, H.J.; Lee, J.H.; Choi, J.W. Microbial decontamination of onion by corona discharge air plasma during cold storage. J. Food Qual. 2018, 2018, 3481806. [CrossRef]

25. Antkowiak, B.; Mańczak, T.; Brzeziński, W. Instruction - Malting Barley Grain; Experimental Station for Variety Assessment, Chemical and Technology Laboratory: Gdańsk, Poland, 2009.

26. EBC-Analytica 3.6.3 Germinative Energy of Barley: Schönfeld Method; Experimental Station for Variety Assessment, Chemical and Technology Laboratory: Nürnberg, Germany, 1997.

27. EBC-Analytica 3.2 Moisture Content; Experimental Station for Variety Assessment, Chemical and Technology Laboratory: Nürnberg, Germany, 1998.

28. EBC-Analytica 3.4 Thousand Corn Weight; Experimental Station for Variety Assessment, Chemical and Technology Laboratory: Nürnberg, Germany, 1998.

29. EBC-Analytica 3.11.1 Sieving Test; Experimental Station for Variety Assessment, Chemical and Technology Laboratory: Nürnberg, Germany, 1998.

30. EBC-Analytica 4.5.1 Extract of Malt: Congress Mash; Experimental Station for Variety Assessment, Chemical and Technology Laboratory: Nürnberg, Germany, 1998.

31. EBC-Analytica 8.17 pH of Wort; Experimental Station for Variety Assessment, Chemical and Technology Laboratory: Nürnberg, Germany, 1998.

32. EBC-Analytica 8.5 Color of Wort: Spectrophotometric Method (IM); Experimental Station for Variety Assessment, Chemical and Technology Laboratory: Nürnberg, Germany, 1998.

33. EBC-Analytica 8.3 Extract of Wort; Experimental Station for Variety Assessment, Chemical and Technology Laboratory: Nürnberg, Germany, 1998.

34. EBC-Analytica 8.10 Free Amino Nitrogen in Beer by Spectrophotometry (IM); Experimental Station for Variety Assessment, Chemical and Technology Laboratory: Nürnberg, Germany, 1998.

35. Zobov, N.F.; Polyansky, O.L.; Le Sueur, C.R.; Tennyson, J. Vibration-rotation levels of water beyond the Born-Oppenheimer approximation. Chem. Phys. Lett. 1996, 260, 381-387. [CrossRef]

36. Michałowska, D.; Salamon, A.; Baranowski, H. Beta-glucanase activity in malt depending on the variety and conditions of the malting process of barley. Zesz. Probl. Post. Nauk Roln. 2011, 556, 143-155. (In Polish)

37. Liszewski, M.; Błażewicz, J. Effect of foliar fertilization with copper and manganese on the malting quality of barley grain (PRELIMINARY STUDY). Pol. J. Agron. 2015, 23, 18-23.

38. Salamon, A. Evaluation of quality of malted grain gluten-free cereals and pseudo-cereals compared to brewery barley malt. PTPRS 2016, 71, 51-74. (In Polish)

39. Salamon, A.; Barannowski, K.; Baca, E.; Michałowska, D.; Zielińska, D.; Kapka, A. Assessment of the content of selected sulfur compounds in beer depending on the quality of malt and heart treatment of the wort. Zesz. Probl. Post. Nauk Roln. 2011, 566, 193-204. (In Polish)

40. Mallet, J. Malt: A Practical Guide from Field to Brewhouse; Brewing Publication: Kalamazoo, MI, USA, 2014; pp. 51-69.

41. Cook, A.H. Barley and Malt: Biology, Biochemistry, Technology; BIRF: Redhill, UK, 1962; pp. 304-305.

42. Angelino, S.A.G.F. On behalf of the Analysis Committee of the EBC. Determination of the moisture and nitrogen contents of barley and malt by near infrared spectroscopy (NIRS). J. Inst. Brew. 1996, 102, 73-74. [CrossRef]

43. Timmer, R.D.; Duijnhouwer, I.D.C.; van Laarhoven, H.P.M.; Angelina, S.A.G.F.; van Son, C.G.M.; Van Gestel, M.J.M.C. Prospects for growing malting barley outsider the southwestern clay district of the Netherlands. Jaarb. Sticht. NIBEM 1993, 57, 39-43.

44. Flores, R.A.; Hicks, K.B.; Wilson, J. Surface abrasion of hulled and hulless barley: Physical characterization of the milled fractions. Cereal Chem. 2007, 84, 485-491. [CrossRef]

45. Kawka, A. Barley and its products. Characteristics, preparation and use in human nutrition. Rocz. AR Poznań, Ser. Rozpr. Nauk. 2004, 342, 1-78. (In Polish)

46. Gurmani, Z.A.; Zia-ul-Hassan, M.; Iran, M.; Jamali, A.R.; Bashir, M. Cost benefit analysis of wheat, barley and oat crops for grain production. J. Agric. Res. 2006, 44, 335-341.

47. Perten, H. Application of The Falling Number Method for Eva Alpha-Amylases Activity. Cereal Chem. 1964, 41, 127-140.

48. Błażewicz, J.; Szwed, Ł.; Kawa-Rygielska, J.; Kupisz, K. Brewing malt and raw materials in the production of food-Type concentrates. Fragm. Agron. 2013, 30, 54-63. (In Polish) 
49. MacGregor, A.W.; Fincher, G.B. Carbohydrates of the barley grain In Barley: Chemistry and Technology; MacGregor, A.W., Bhatty, R.S., Eds.; AACC, Inc.: St. Paul, MN, USA, 1993; pp. 73-130.

50. Osborne, T.B. The Vegetable Proteins; Longmans, Green and Co.: London, UK, 1924.

51. Shewry, P.R. Barley seed proteins. In Barley: Chemistry and Technology; MacGregor, A.W., Bhatty, R.S., Eds.; AACC, Inc.: St. Paul, MN, USA, 1993; pp. 131-197.

52. Jones, B.L. Endoproteases of barley and malt. J. Cereal Sci. 2005, 42, 139-156. [CrossRef]

53. Celus, I.; Brijs, K.; Delcour, J.A. The effects of malting and mashing on barley protein extractability. J. Cereal Sci. 2006, 44, 203-211. [CrossRef]

54. Jin, Y.; Du, J.; Zhang, K.; Xie, L.; Li, P. Relationship between Kolbach index and other quality parameters of wheat malt. J. Inst. Brew. 2001, 118, 57-62. [CrossRef]

55. Przulj, N.; Momcilovic, V. Genetic variation for dry matter and nitrogen accumulation and translocation in two-rowed spring barley. I. Dry matter translocation. Eur. J. Agron. 2001, 15, 241-254. [CrossRef]

56. Künbeck, F.; Bach, W.; Krottenthaler, M. Influence of lauter turbidity on wort composition, fermentation performance and beer quality. J. Inst. Brew. 2006, 112, 214-221.

57. Royston, M.G. Wort boiling and cooling. In Modern Brewing Technology; Findly, W.P.K., Ed.; MacMillan Press: London, UK, 1971; pp. 77-79.

58. Rybacek, V. Hop Production; Elsevier Science Publication: Amsterdam, The Netherlands, 1991.

(C) 2020 by the authors. Licensee MDPI, Basel, Switzerland. This article is an open access article distributed under the terms and conditions of the Creative Commons Attribution (CC BY) license (http://creativecommons.org/licenses/by/4.0/). 